\section{Leukon Synthetic Resin}

A NEW synthetic resin known as 'Leukon' was exhibited in granular thermo-plastic moulding form at the British Industries Fair by Imperial Chemical Industries, Ltd. The main physical properties of the material are stated to be as follows: density 1.2 at $20^{\circ} \mathrm{C}$., impact strength $4 \mathrm{kgm}$. cm. (Charpy units), tensile strength up to $10,000 \mathrm{lb}$. per sq. in., eross breaking strength $80 / 85 \mathrm{lb}$. eantilever, Young's modulus 227 tons per sq. in. The material flows before breakdown under high pressure. As regards the chemical properties of the material, it is said to be insoluble in water, alcohol and aqueous media, to be unaffected by acids or alkalies up to concentra. tions of 40 per cent in the case of sulphuric acid and caustic soda at atmospheric temperature, and to be unaffected by many high boiling organic esters. It is soluble in certain of its forms in a number of organic solvents, including acetone, chlorinated hydrocarbons and benzene. The material machines easily, can be die-stamped at $120^{\circ}-140^{\circ}$, has very good insulating properties and low thermal conductivity. A property which is emphasised is the capacity of the material for colour, in transparent, translucent or opaque forms.

\section{The Prehistoric Society of East Anglia}

Aт the recent annual meeting of the Prehistoric Society of East Anglia, held at the Norwich Castle Museum, it was resolved that in future the title of the Society shall be "The Prehistoric Society". Dr. J. G. D. Clark, in proposing the change, directed attention to the fact that the Society is no longer predominantly East Anglian either in membership or scope of work, and emphasised the point that the recognition of the Prehistoric Society as the only society operating on a national basis exclusively in the sphere of prehistoric archæology will be a contribution towards the much-desired rationalisation of the subject in Great Britain. The Prehistoric Society of East Anglia was founded in 1908 by the late Dr. Allen Sturge and the late W. G. Clark of Norwich. From very small beginnings it has grown until the membership now approaches 400 and includes the leading prehistorians in this and many other countries. Prof. L'Abbé Henri Breuil, the retiring president, is succeeded by Prof. V. Gordon Childe, with Mr. M. C. Burkitt as vice-president, Dr. J. G. D. Clark as editor and Mr. G. Maynard, curator of the Ipswich Museum, as honorary secretary.

\section{The Philosophy of Sir James Jeans}

Is the December number of Adult Education, Prof. L. Susan Stebbing subjects Sir James Jeans's recent presidential address to the British Association to searching criticism. She complains that he has rated the intelligence of his hearers and readers too low by presenting them with contradictory statements concerning Nature, space and time, and knowledge. Some of the questions raised were referred to in our leading article on the address which was published in NaTURE of September 8 last, but Prof. Stebbing makes no attempt to penetrate to the vital ideas which were expressed, however imperfectly, by Sir James Jeans; she contents herself with pointing out the imperfections. As destructive criticism, the paper is of value, though, in the absence of counter-balancing constructive thought, it achieves less than its full potentialities. Prof. Stebbing fortunately does not make the common error of supposing that a single statement, by however distinguished a physicist, represents the unanimous view of 'physics'. "The point to be maintained here," she says, "is that these cloudy speculations cannot properly be regarded as 'philosophical implications' of the new 'physics'." This goes far to justify what might otherwise be construed as a philosopher's attack on the philosophical tendencies of modern physics.

\section{Biology, a new Journal}

WITH the object of helping teachers of biology in different types of schools at home and abroad, the British Social Hygiene Council has launched a new journal, Biology. It is hoped that the magazine will "serve as a medium for the interchange of ideas and information on practical and pioneer ventures in biology teaching". The scope of Biology is suggested by the articles in the first number. They include one advocating microscope work, dissection and physiology of growth and development in elementary biology teaching; another describing the methods in use in African dependencies. More general articles deal with plant communities and the school; the value of the micro-projector; biological activities out of school; and biology and general science in the First School Examination. The hesitation and delay in the introduction of biological teaching in schools throughout Great Britain is due largely to the indefiniteness of the subject's boundaries, and the lack of well. organised graded courses of fairly definite content. If Biology can lead to the development of such courses by pooling information, it will be performing great service to the science of life.

\section{Research on Causes of Blindness}

Mr. Wruliam H. Ross, chairman of the Distillers' Company, Ltd., who is himself totally blind, has recently given $£ 40,000$ to establish in Edinburgh an organisation "with the object of investigating the origin and causes of blindness, and utilising the results of such investigation towards its prevention and cure". The income from the money will be applied partly to research work on blindness, and partly to practical measures for its prevention and for the preservation of sight. The chairman of the trustees is Dr. Arthur H. H. Sinclair, president of the Royal College of Surgeons of Edinburgh.

\section{New Australian Research Laboratories}

Two new research laboratories are to be built for the Commonwealth Council for Scientific and Industrial Research, using money voted for relief of

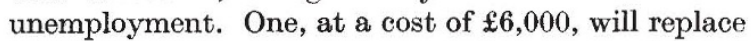
an existing small building at the Council's viticultural research station near Mildura on the River Murray, 
where investigations into problems of the dried grape fruits industry have been in progress for many years. The other will house the Forest Products Division, which hitherto has carried on in temporary quarters in Melbourne. The new laboratory, to cost $£ 25,000$, will be in the midst of the city's timber yards, and this should mean decided increase in the practical effectiveness of the Division's work.

\section{Geographical Association}

The Spring Conference of the Geographical Association will be held at University College, Nottingham, on April 26-29. The meeting will include, in addition to several lectures and discussions, a long excursion to Southwell and Ollerton and visits to the tobacco factory of Messrs. J. Player and Sons, the hosiery factory of Messrs. J. B. Lewis and Sons, and Messrs. Boots new chemical factory. Members will be accommodated as far as possible in the Hugh Stewart Hall of Residence. Applications for accommodation and attendance at excursions should be made, before April 6, to Mr. N. V. Scarfe, University College, University Park, Nottingham.

\section{Astronomical Exhibition in Paris}

At the next General Assembly of the International Astronomical Union, to be held at Paris on July 10-17, the French National Committee of Astronomy is arranging an exhibition of astronomical documents and apparatus, to exhibit the principles and the details of application of the methods of observation employed. The examination of actual instruments shows better than any description how they are applied, while original negatives or positives on glass will enable the quality of the results obtained to be judged. The exhibition will enable astronomers to examine the documents serving as the foundation of the astronomical discoveries of the present century. It is particularly hoped that auxiliary apparatus and accessory contrivances of all kinds will be exhibited by observatories and instrument makers: such instruments are micrometers, chronographs, photometers, spectrographs, driving motors, observing sheds and seats, abacuses, numerical tables and calculating machines. Inquiries can be addressed to M. le Comte de la Baume Pluvinel or to Prof. C. Fabry at the Paris Observatory.

\section{Sixth International Congress for Scientific Management}

THE Sixth International Congress for Scientific Management, the first congress of its kind to be held in Great Britain, will take place on July 15-20 and will be opened by its patron, the Prince of Wales. It will discuss commercial, agricultural and domestic problems and how far the adoption of the most scientific principles of management has facilitated their solution. Some three hundred chairmen, managing directors and professional and scientific men have so far enrolled, and the standard of the papers received from all parts of the world is most encouraging. The organisation of the Congress is in the hands of a Council convened by the Federation of British Industries. Subjects to be discussed include : manu- facturing, distribution, development, agricultural, educational and training, and domestic. There is every indication that a really important gathering will take place. H.M. Government is to invite members to a reception, and the Lord Mayor and Corporation will receive them in the Guildhall. A series of visits to factories and institutions will take place in the week following the Congress. Invitations to the Congress containing membership forms and full details may be obtained from the Secretary, 21 Tothill Street, London, S.W.1.

\section{Catalogue of Microscopes and Accessories}

We have received from Messrs. W. Watson and Sons, Ltd., the new edition of their catalogue of microscopes and accessories (Parts 1 and 2). The pages devoted to principles of construction on the optical bench system, now applied to all Messrs. Watson's microscopes, are of particular interest, and other constructional details in these pages are also noteworthy as evidence of the care devoted to the attainment of rigidity and accuracy. Attention may also be directed to the description of the dark ground condenser which can be made with working distances up to $4 \mathrm{~mm}$. and to the low-power binocular dissecting microscope, strong in build and with two pairs of objectives mounted on a double nosepiece so arranged that the pair not in use is turned into a protected position. A considerable range of lamps for various microscopic purposes includes the Greenough lamp, which rests on the table beneath the microscope stage in place of the mirror and gives an evenly illuminated field, provision being made for centring the filament.

\section{Announcements}

Sir John Ambrose Fleming has been awarded the Kelvin Medal for 1935 of the Institution of Civil Engineers in recognition of his services to electrical science and particularly of his invention of the thermionic valve. The Kelvin Gold Medal is awarded triennially as a mark of distinction in engineering work or investigation of the kinds with which Lord Kelvin was especially identified.

Aт the meeting of the Australian National Research Council at Melbourne in January, the first award of the Lyle Medal was made, the recipient being Prof. J. R. Wilton, Elder professor of mathematics in the University of Adelaide, for his work in mathematics. This medal is to be awarded, at intervals of two years, to workers in Australia for such researches in mathematics or physics as may appear to the Council most deserving of such honour, the period covered by those researches being the five years preceding each award.

THE services of Prof. R. H. Dastur, professor of botany at the Royal Institute of Science, Bombay, have been secured on loan from the Bombay Government by the Government of the Punjab for the investigation of the cotton crop. His address for some years, therefore, will be the Cotton Research Laboratory, Lyallpur, Punjab. 